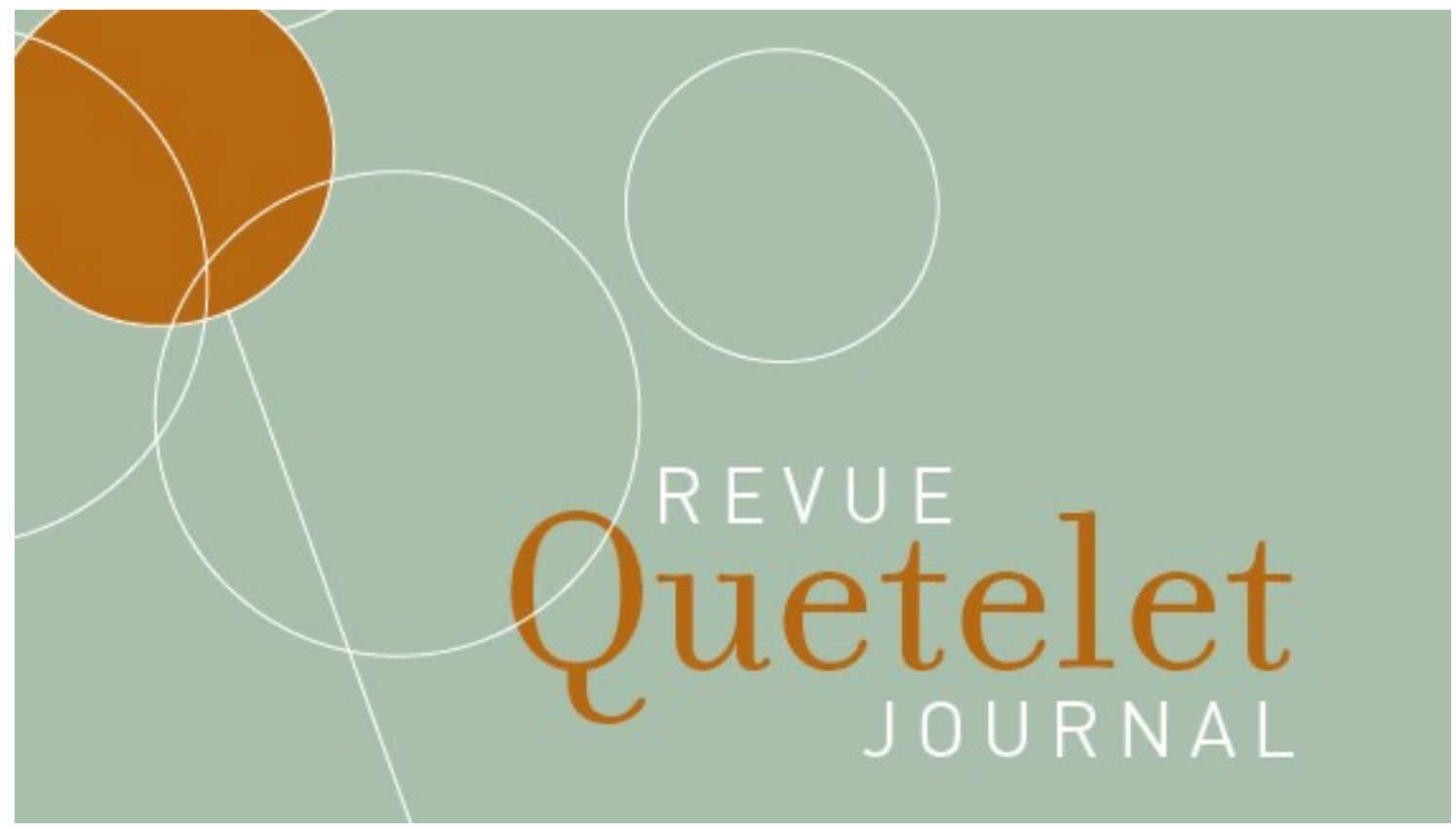

Vol. 5, n 1 , avril 2017, pp. 73-98

DOI : $10.14428 /$ rqj2017.05.01.03

ISSN: 20349378

\title{
Entry into motherhood during adolescence in France
} A sociodemographic and spatial analysis of the determinants and profiles

John Tomkinson, Dider Breton, Magali Mazuy

This work is licensed under a Creative Commons Attribution-NonCommercial 4.0 International License. You can share, adapt the material for non-commercial purposes provided that you give appropriate credit and indicate if changes were made. For details see https://creativecommons.org/licenses/by-nc/4.0/

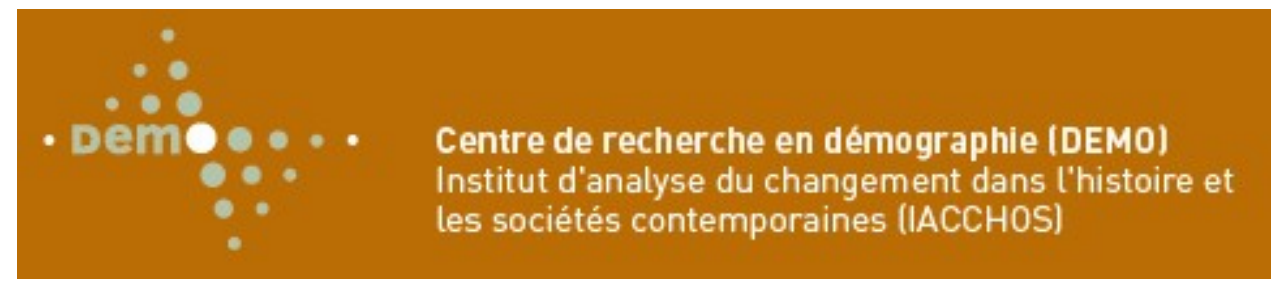





\title{
Entry into motherhood during adolescence in France \\ A sociodemographic and spatial analysis of the determinants and profiles ${ }^{1}$
}

\author{
JOHN TOMKINSON ${ }^{2,3}$ \\ DIDIER BRETON ${ }^{3}$ \\ MAGALI MAZUY ${ }^{2}$
}

\begin{abstract}
Résumé
En France métropolitaine, le niveau de fécondité des adolescentes (femmes de 18 ans et moins) varie d'une région à une autre. Cet article montre d'abord que les différences régionales ne résistent pas à une standardisation par des caractéristiques sociodémographiques de la population des adolescentes. L'autre résultat important est la mise en évidence de quatre profils de mères adolescentes, profils inégalement répartis dans les régions métropolitaines.

Mots-clés

Maternité des adolescentes, profils sociodémographiques, disparités régionales, méthode du «décompte d'enfants au foyer», France.

Abstract

In mainland France and Corsica, the level of teenage fertility (of women aged 18 and less) varies from one region to another. This article first of all shows that these regional differences do not remain once standardizing for the sociodemographic characteristics of the female teenage population. The article then highlights from profiles of teenage mothers which are unequally distributed amongst the French regions.
\end{abstract}

1. The present research has benefitted from financial support from the labex iPOPs, organised by Ined, under the reference ANR-10-LABEX-0089, in the context of heSam Université.

2. Institut National d'Études Démographiques (INED), Paris, France.

3. Institut de Démographie de l'Université de Strasbourg; Member of the Sociétés, Acteurs, Gouvernement en Europe (UMR 7363) Laboratory. 


\section{Keywords}

Teenage motherhood, sociodemographic profiles, regional disparities, Own-children method, France.

\section{Introduction}

In metropolitan France, as is the case with total fertility (Prioux, Mazuy, 2009; Desplanques, 2011), large geographical disparities in adolescent fertility exist. Adolescent fertility is highest in the northern regions ${ }^{4}$ of France: Nord-Pas-de-Calais Picardie ( 82 births per 10'000 women aged 15-18 years old), Normandie (47 per 10'000) and Alsace ChampagneArdenne Lorraine (47 per 10'000). At the opposite end of the scale teenage fertility is lowest in Bretagne (25 per 10'000) and Corse (26 per $10^{\prime} 000$ ) (Figure 1). The contribution of teenage fertility to the total fertility rate (TFR) is highest where the adolescent fertility rate is highest (Figure 1) thus signalling an absence of correlation between the level of teenage fertility and the TFR. In this article we consider teenage fertility as a phenomenon in its own right, independent of total fertility. Incidentally, the theorists of the Second Demographic Transition consider this phenomenon as independent of the mechanisms which explain the evolution towards fertility regimes of low and indeed very low fertility 5 .

This article attempts to respond to two questions. Firstly, do the regional differences in teenage fertility remain once we control for the sociodemographic variables classically cited as being determinants of the fertility of adolescents? Secondly, what are the sociodemographic profiles of teenage mothers? Are some of these profiles over-represented in certain regions?

\footnotetext{
4. Our analysis in this article concerns the 13 «new» French regions ( $c f$. Appendix 1) defined legally in January 2015 (la Loi du 16 janvier 2015).

5. Comments of Ron Lesthaege during the Chaire Quetelet 2014 «Fécondité, infécondité et famille, approche interdisciplinaire», Louvain-la-Neuve, 5-7 novembre 2014.
} 
FIgURE 1 Annual standardized fertility rate for women aged 15-18 (left) and contribution of fertility rates from 15 to 18 years old to the total fertility rate (right), French regions, 2010
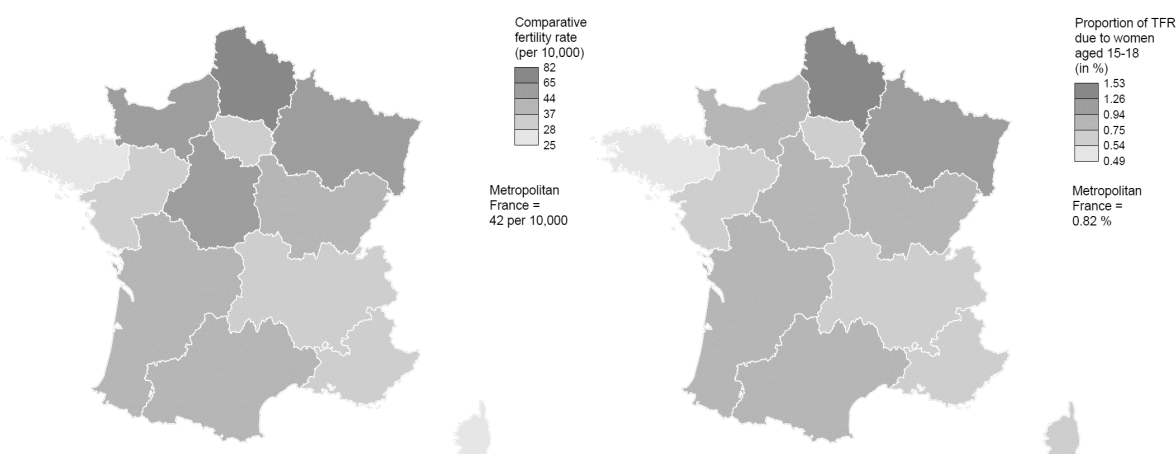

Sources: Insee État Civil 2010; Insee RP 2010, 2011; IGN GEOFLA ${ }^{\circledR}$.

Scope: Metropolitan France.

Note: Age is calculated in terms of age attained in the calendar year. The denominator is the average female population in 2010, calculated (by the authors) via the populations enumerated at the 1st of January in 2010 and 2011. Births at 15 years old and under were related to the population aged 15 and births at 45 years old and above to the population aged 45 . Fertility rates are standardized by the female population of metropolitan France aged 15 to 18.

\section{European context and review of existing literature}

Teenage births represent a resistance to the general trend of an increase in age at first birth, a distinguishing feature of the evolution of fertility in developed countries (Ní Bhrolcháin, Beaujouan, 2012) and characteristic of the Second Demographic Transition (Lesthaege, van de Kaa, 1986). In France, the average age at first birth has increased from 24 to 28 years old in the space of 40 years (Pison, 2010). Each culture has its norms relative to the «right» age to become a parent (Van Bavel, Nitsche, 2013), and in western countries an early entry into parenthood goes against the norm of transition to adulthood characterized by the sequence of end of studies, first job, leaving home, couple formation and finally, a first child (Battagliola et al., 1997a, 1997b; Galland, 1995, 2000). The early arrival of a child in a woman's life course highlights a contradiction between physical maturity - to be physiologically able to have a child - and social maturity - the ability to provide for their needs (Daguerre, 2010). This «opposition» is at the origin of the majority of fears used to justify policies aiming to prevent teenage pregnancies. 
If in France the contribution of teenage fertility towards the total fertility rate is of a relatively average level (Figure 2), a far cry from that observed for example in the United Kingdom - a unique case in Europe (Ekert-Jaffé et al., 2002); that does not prevent teenage pregnancies being considered as «a particular situation, disconcerting, which raises medical and social problems, and questions about contraception and the capacity of being a mother» (Genest et al., 2014, p. 3526). In Europe the perception of this phenomenon as a problem does not seem to be linked to its frequency (Rowlands, 2010).

FIGURE 2 Sum of annual age-specific fertility rates from 15 to 18 years (top) and contribution of fertility rates from 15 to 18 years old to total fertility rate (bottom), selected European countries, 1998-2013

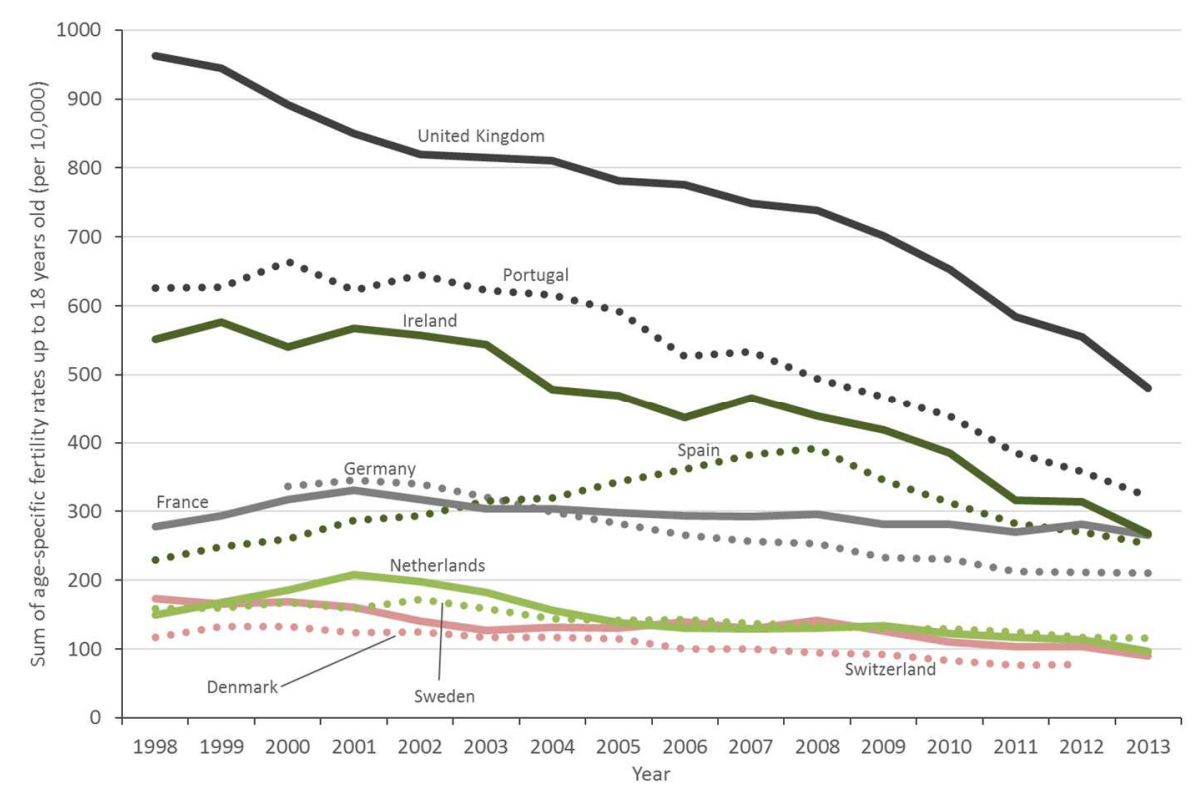

6. Translated from French by the authors. 


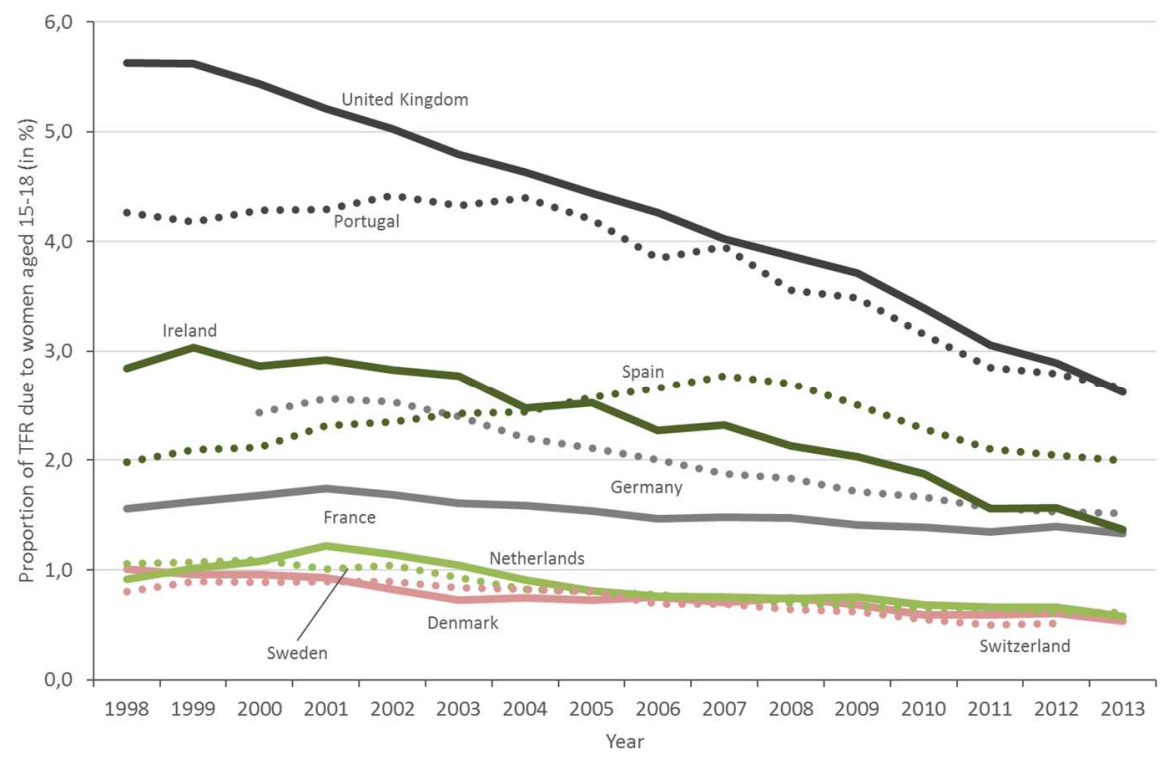

Source: Eurostat

Note: Data from the Eurostat database are published in age at last birthday which produces higher fertility rates and contributions to TFR than the same indicators calculated using age attained in the calendar year, such as those presented in figure 1. This fact explains the higher values for France in 2010 in Figure 2 than in Figure 1.

In the existing literature ${ }^{7}$, the sociodemographic, economic and cultural determinants of teenage births are studied principally at an individual level even though some analyses choose other scales of influence, for example familial, local or cultural norms. Studies at the family level pose the hypothesis of a transmission of norms and attitudes regarding early motherhood from one generation to the next, or more precisely from mother to daughter (Stanfors, Scott, 2013; Rendall, 2003; Manlove, 1997). If some studies show a modest contribution of this phenomenon of intergenerational transmission (Rendall, 2003), others highlight the correlation between early motherhood and the fact of being part of a large offspring (Russell, 2002), or the fact of having grown up in a single-parent family (Robson, Pevalin, 2007). Studies at a local level attempt to verify the effect of a woman's entourage and of the geographical context upon the probability of becoming a mother at a young age. Some authors evoke «local cultures of early fertility» and through a spa-

7. Existing literature on teenage motherhood is principally Anglo-Saxon given the specific situation with regards to high levels of teenage fertility in these countries (e.g. USA, UK, Canada, Australia and New Zealand). 
tial analysis of the phenomenon in the UK, show that a half of all teenage conceptions occur in the first quintile of the most deprived wards $^{8}$ (Arai, 2007). Also in the UK, Smith (1993) observed a fertility rate for women aged under 16 three times higher in the most deprived postcodes compared to the least deprived. Numerous studies show that young mothers are often from poorer backgrounds (Robson, Pevalin, 2007) and exhibit social disadvantages such as experiencing unemployment, poverty and discrimination (Rowlands, 2010), a lack of economic opportunities and social exclusion (Kearney, Levine, 2012).

In spite of these contextual effects, it is the individual determinants of teenage childbearing that take precedence (McCulloch, 2001). Several individual sociodemographic characteristics are associated with early motherhood and we will examine the pertinence of these relations in the case of France, hitherto the subject of few quantitative studies.

The level of education (Cook, Cameron, 2015; Lupton, Kneale, 2010) and the schooling of young women is another strong determinant of the probability of experiencing a maternity during adolescence. Battagliola et al. (1997b) demonstrated that for women born in the 1960s, the proportion of women having become a mother at a young age was inversely proportional to their level of diploma. In the context of the transition to adulthood, the authors argue that a high level of diploma leads to a longer period of education which reflects a choice to invest primarily in their professional life rather than their family life. Inversely, a weaker level of diploma is a handicap to accessing the job market, which could incite women to invest more in their family environment when faced with a lack of professional opportunities. Beyond the level of qualification, dropping out of school is associated with teenage motherhood (Charbonneau, 2000; Wellings et al., 2001; Cater, Coleman, 2006). More generally, Ní Bhrolcháin and Beaujouan (2012) show a link between the timing of the end of education and the postponement of entry into motherhood in France and the United Kingdom.

Economic theories also exist which argue that for teenage women no longer in education or with a low level of qualification, the opportunity cost of having a child at a young age is less (Girma, Paton, 2015) as the conflict between the role of student and potential mother no longer exists (Ní Bhrolcháin, Beaujouan, 2012). The impact of leaving education on the risk of becoming a teenage mother is twofold by increasing both

8. The smallest political administrative geographic unit existing in the UK of which there are more than nine thousand (Office for National Statistics). 
the probability of a conception and the chances that the pregnancy will result in a live birth rather than in an abortion (Leibowitz et al., 1986).

An absence of professional activity is equally associated with teenage mothers (Genest et al., 2014; McCulloch, 2001). It is however difficult to know if this inactivity is the cause or the consequence of a teenage birth, although the work of Battagliola et al. (1997a, 1997b) seems to suggest that often inactivity precedes the birth of a first child, the entry into family life thus preceding the entry into professional activity.

Finally, the ethnic and cultural origin of women can influence their risk of experiencing a teenage birth. For example, comparatively higher teenage fertility rates have been observed in the UK amongst teenage women of Caribbean, Pakistani and Bangladeshi origin and lower rates amongst those of Indian, African and Chinese origin (Berthoud, 2001; Coleman, Dubuc, 2010). These trends are in part due to cultural differences relative to the age at marriage and family formation: the vast majority of births amongst teenage women of South-East Asian origin in the UK being within marriage (Berthoud, 2001).

\section{Method}

\section{Identifying teenage mothers in the French census}

Birth registration data in France is an insufficient source for a differential analysis of teenage fertility given the few sociodemographic variables contained in the birth registration form ${ }^{9}$.

We use microdata from the 2011 French census which is the lone source permitting a differential analysis representative at regional level. The identification of women having become a mother as a teenager is based upon the principals of the "Own Children» method (OCM) (Grabill, Cho, 1965). This method uses the links established between the children and their mother within a family (as defined by the census) to determine the age of the mother at birth by simple subtraction of the age of the child from the age of its mother. The objective of this article being to identify

9. Cf. extract of birth registration form in Appendix 2. Only the activity, profession, situation professional and the nationality of the mother are collected, albeit with varying quality (Davie, Mazuy, 2010). No information is collected concerning the level of education of the mother, status of couple or living arrangements (e.g. does she still live with her parents). 
the characteristics of the mother at the moment of the birth, we concern ourselves only with the mothers of children born in the year preceding the census ${ }^{10}$ (that we note $t-1$ ), thus reducing the duration between the birth and the census and any eventual changes in sociodemographic characteristics of the mother between these two events.

In its original form, the Own Children method has difficulty in linking a child to its mother when the latter is very young (Desplanques, 2008, 1993; Abbasi-Shavazi, 1997). These children are falsely linked to older mothers, an error at the origin of an underestimation of the number of teenage mothers and an overestimation at older ages. We use a refined version of this method which reduces the «under-identification» of teenage mothers from $46 \%$ (classic version of Own Children method) to 23\% (refined method) (Tomkinson, Breton, 2016).

Of the 1'442'543 women aged 16 to 19 years old enumerated in ordinary households in metropolitan France in 2011 (reference population), 4'446 are identified as having had a child in the year preceding the census.

\section{Descriptive statistics}

The descriptive statistics presented here have for objective to measure both the «risk» of becoming a teenage mother within different subpopulations but also to characterize the women having becoming a mother during their adolescence. Some characteristics can be associated with an increased risk of becoming a teenage mother without the prevalence of these characteristics being high amongst teenage mothers. Thus in the UK, although the risk of experiencing a birth as a teenager is higher amongst married teenage women, $96 \%$ of teenage conceptions in the UK result from unmarried women (Cook, Cameron, 2015).

10. Since 2004, the French census is a rolling census based upon the accumulation of five annual census surveys (enquêtes annuelles de recensement (EAR)). Each year, in municipalities of $10^{\prime} 000$ or more inhabitants, $8 \%$ of households are enumerated as well as all households in 1 in 5 municipalities with less than 10'000 inhabitants (Lefranc, 2009). At the end of a 5 year cycle, around $70 \%$ of households have been enumerated. The data from the 5 EARs are grouped and the results are published for the median year of the EARs. Thus the 2011 census which we exploit in this article is based upon the EARs of 2009 to 2013 and thus the mothers that we identify gave birth to their children between 2008 and 2012 . 
We construct two indicators:

- the observed frequency of teenage mothers amongst all teenage women having a certain characteristic, noted $f_{i, k}$

$$
f_{i, k}=10^{\prime} 000 \times \frac{m_{i, k}}{g_{i, k}}
$$

Where, $f_{i, k}$ is the observed frequency of teenage mothers having the characteristic $k$ of the variable $i$ per $10^{\prime} 000$ women aged 15 to 18 years old having this same characteristic in the year $t-1 ; m_{i, k}$ is the number of teenage mothers having the characteristic $k$ of the variable $i ; g_{i, k}$ is the number of women aged 15 to 18 years old having the characteristic $k$ of the variable $i$.

- the proportion of teenage mothers having a certain characteristic amongst all mothers, noted $s_{i, k}$

$$
s_{i, k}=100 \times \frac{m_{i, k}}{\sum_{1}^{k} m_{i, k}}
$$

Where, $s_{i, k}$ is the percentage of teenage mothers having the characteristic $k$ of the variable $i$; $m_{i, k}$ is the number of teenage mothers having the characteristic $k$ of the variable $i$.

These two indicators are close to notions of «risk» $\left(f_{i, k}\right)$ and «prevalence» $\left(s_{i, k}\right)$ (Breton, Prioux, 2009).

\section{Regression upon characteristics associated with a teenage birth, a regional approach}

In order to judge the significance of regional effects, we construct a series of logistic regression models (where $\mathrm{Y}=1$ corresponds to having given birth to a child in the year preceding the census) with, in addition to the region of residence, a certain number of sociodemographic variables as independent variables ${ }^{11}$.

The control variables used come from census microdata: age (in the year preceding the census), couple status, indicators of living with parents and living in social housing, level of qualification, activity and immigration status ${ }^{12}$.

11. The region Pays de la Loire was chosen as reference situation as the proportion of teenage mothers observed there is the closest to the proportion seen in metropolitan France (31.9 per $10^{\prime} 000$ compared to 30.8 ). We would like to know if any regions distinguish themselves from the national trend.

12. Immigration status was preferred to nationality as it remains unchanged over time as opposed to nationality which can be acquired. 


\section{Typology and spatial variation of sociodemographic profiles of teenage mothers}

Finally, by using a method of hierarchical classification ${ }^{13}$, we establish a typology of teenage mothers from five active variables used in the logistic regression models: couple status, indicators of living with parents and living in social housing, level of qualification, activity. We then examine the relative geographical distribution of each group of teenage mothers in the French regions by measuring the relative overrepresentation in each region of each group of teenage mothers.

\section{Results}

\section{Descriptive statistics}

The descriptive statistics (Table 1) confirm first of all the different frequency of teenage motherhood by region. In the region Nord-Pas-deCalais Picardie, for 10'000 teenage women enumerated, 53 had given birth in the year $t-1$ compared to 31 in the overall population. The lowest frequency ( 21 per $10^{\prime} 000$ ) is observed in the Ile-de-France and Auvergne Rhône-Alpes regions.

As expected we also notice an important effect of age, the frequency of mothers increasing with age (from 6 per $10^{\prime} 000$ at 15 years old to 77 per $10^{\prime} 000$ at 18 years old).

If the frequency of married teenagers having given birth in the year $t-1$ (more than one in ten) is relatively large compared to non-married teenagers, they represent only a small proportion of teenage mothers $(6 \%)^{14}$. Similar patterns are seen in the variables «living in social housing» and «place of birth»: if the frequency of teenage mothers is higher amongst the population living in social housing and among those teenage women born abroad, the majority of teenage mothers are not living in social housing and were born in France.

\footnotetext{
13. Ward's method: undertaken with SAS 9.4 (PROC CLUSTER).

14. This proportion is higher than amongst the population of teenage women not having had a child (3.5\% compared to $0.2 \%-c f$. Appendix 3 ). We show that when compared to the population of teenage women not having had a child in the year preceding the census teenage mothers distinguish themselves significantly: they are older, more often in a couple, less often living with their parents and less often a student. Teenage women having had a child are thus a very specific sub-population.
} 
TABLE 1 Proportion of teenage women having given birth in the year $t-1\left(f_{i, k}\right)$ by sociodemographic characteristics and sociodemographic distribution of these teenage mothers $\left(s_{i, k}\right)$

\begin{tabular}{|c|c|c|c|c|c|}
\hline Variable $(i)$ & Modality $(k)$ & $\mathrm{N}$ & $\begin{array}{l}\mathrm{Nb} \text { of } \\
\text { teen- } \\
\text { age moth- } \\
\text { ers ob- } \\
\text { served }\end{array}$ & $\begin{array}{c}f_{i, k} \\
(\text { per } \\
10,000)\end{array}$ & $\begin{array}{l}S_{i, k} \\
(\%)\end{array}$ \\
\hline \multirow[t]{13}{*}{ Region } & Ile-de-France & $279^{\prime} 783$ & 589 & 21 & 13 \\
\hline & Auvergne Rhône-Alpes & $176^{\prime} 666$ & 374 & 21 & 8 \\
\hline & Nord-Pas-de-Calais Picardie & $146^{\prime} 795$ & 774 & 53 & 17 \\
\hline & Aquitaine Limousin Poitou-Charentes & $120^{\prime} 088$ & 422 & 35 & 9 \\
\hline & Languedoc-Roussillon Midi-Pyrénées & $123^{\prime} 757$ & 425 & 34 & 10 \\
\hline & Alsace Champagne-Ardenne Lorraine & $126^{\prime} 250$ & 458 & 36 & 10 \\
\hline & Provence-Alpes-Côtes-d'Azur & $110^{\prime} 719$ & 282 & 26 & 6 \\
\hline & Pays de la Loire & $83^{\prime} 884$ & 267 & 32 & 6 \\
\hline & Normandie & 77’654 & 285 & 37 & 6 \\
\hline & Bretagne & $72^{\prime} 608$ & 192 & 26 & 4 \\
\hline & Bourgogne Franche-Comté & $61^{\prime} 737$ & 209 & 34 & 5 \\
\hline & Centre-Val de Loire & $56^{\prime} 243$ & 153 & 27 & 3 \\
\hline & Corse & 6’358 & 15 & 24 & 0 \\
\hline \multirow[t]{4}{*}{$\operatorname{Age}^{(\mathrm{i})}$} & 15 & $362^{\prime} 385$ & 216 & 6 & 5 \\
\hline & 16 & $365^{\prime} 033$ & 471 & 13 & 11 \\
\hline & 17 & $366^{\prime} 312$ & $1^{\prime} 089$ & 30 & 24 \\
\hline & 18 & $348^{\prime} 812$ & $2^{\prime} 670$ & 77 & 60 \\
\hline Immigration & Immigrant & $58^{\prime} 419$ & 435 & 74 & 10 \\
\hline status & Non immigrant & 1'384'124 & $4^{\prime} 011$ & 29 & 90 \\
\hline Couple status & In a couple (married) & 2'455 & 272 & 1'108 & 6 \\
\hline \multirow[t]{2}{*}{ (marital status) } & In a couple (single) & $25^{\prime} 877$ & $1^{\prime} 817$ & 702 & 41 \\
\hline & Not in a couple & $1^{\prime} 414^{\prime} 211$ & $2^{\prime} 356$ & 17 & 53 \\
\hline Lives with & Yes & 1'317'094 & 1'196 & 9 & 27 \\
\hline parents & No & $125^{\prime} 449$ & $3^{\prime} 250$ & 259 & 73 \\
\hline Lives in social & Yes & $286^{\prime} 364$ & $1^{\prime} 435$ & 50 & 32 \\
\hline housing & No & 1'156'179 & 3’011 & 26 & 68 \\
\hline Level of & Lower than middle school diploma & $275^{\prime} 864$ & $2^{\prime} 112$ & 77 & 48 \\
\hline \multirow[t]{3}{*}{ qualification } & Middle school diploma & $835^{\prime} 585$ & $1^{\prime} 239$ & 15 & 28 \\
\hline & Vocational high school diploma (ii) & $134^{\prime} 729$ & 763 & 57 & 17 \\
\hline & High school diploma ${ }^{(i i i)}$ or higher & $196^{\prime} 364$ & 332 & 17 & 7 \\
\hline \multirow[t]{4}{*}{ Activity } & Active, in employment & $94^{\prime} 239$ & 305 & 32 & 7 \\
\hline & Unemployed & $56^{\prime} 779$ & $1^{\prime} 024$ & 180 & 23 \\
\hline & Student & 1'253'692 & $1^{\prime} 064$ & 8 & 24 \\
\hline & Inactive & $37^{\prime} 833$ & 2'053 & 543 & 46 \\
\hline \multicolumn{2}{|l|}{ Total } & 1'442'543 & $4^{\prime} 446$ & 31 & 100 \\
\hline
\end{tabular}

Scope: Women aged 15 to 18 years old in ordinary households, metropolitan France, year $t-1$.

Source: Insee RP 2011 (weighted data).

Notes: (i) Age (expressed in age attained in the calendar year) in the year preceding the census, thus age at birth for the mothers; (ii) CAP: Certificat d'aptitudes professionnelles; BEP: Brevet d'études professionnelles; (iii) Baccalauréat. 
On the contrary, the values of $f_{i, k}$ and $s_{i, k}$, follow the same hierarchy for the modalities of the other sociodemographic variables. This is the case for parental non-cohabitation (the frequency of mothers amongst teenage women no longer living with their parents is 259 per $10^{\prime} 000$ - as opposed to 9 per $10^{\prime} 000$ for the others - and the majority of teenage mothers (73\%) have left home. The same situation is seen for the modalities of the variables «level of qualification» and «activity».

\section{Individual characteristics take precedence over region of residence}

The construction of a series of complementary log-log regression models (Table 2) shows that the individual sociodemographic characteristics of women explain the majority of the variance in the probability of having had a child in the year $\mathrm{t}-1$ explained in the models ${ }^{15}$. This result signifies that the majority of the geographic variation in the phenomenon of teenage motherhood is due to the effects of differing socioeconomic and demographic compositions of the women residing there and not due to a strictly spatial effect.

Amongst the individual sociodemographic characteristics used in our models, the fact of being inactive (predicted probability of 132 per $10^{\prime} 000$ ), and to a lesser extent being unemployed (41 per 10'000), has the largest effect. Introducing this variable (model 3) increases the percentage of variation explained by the models from 30\% to 38\% (passage from model 2 to 3 ) and eliminates the effects of a very low level of qualification and of being relatively older (18 years old). These results seem to validate the hypothesis of a relation between economic status and entry into parenthood. The opportunity cost of a birth is lower for inactive or unemployed teenage women, whatever their level of qualification or age. Moreover they accredit the theory of transition to adulthood - unable to become an adult by way of employment, those inactive or unemployed obtain the adult status through motherhood. It could be argued that the inactivity associated with a teenage entry into motherhood is a consequence of the birth itself which acts as a constraint to

15. Given the size of the sample included in our models (more than 1.4 million observations, around $70 \%$ of the population) all variables will be significant in the regression models when using «conventional» $\mathrm{p}$-value thresholds. The addition of variables to the model was judged against the contribution to the share in the variance explained in the model (Nagelkerke's $\mathrm{R}^{2}$ ). The reported p-values are facultative, with very conservative thresholds being used. In the text we report the relative effect sizes of the modalities associated with the predicted probability of having given birth as an adolescent in the year $\mathrm{t}-1$. 
economic activity (or the continuation of education). Although our snapshot of sociodemographic characteristics of very young mothers is taken a short time after the birth, as previously stated, Battagliola et al. (1997a) show that inactivity often precedes the birth of a child amongst very young mothers, thus this result is unlikely to be affected by a bias of temporality.

The level of qualification also plays a significant role. A higher level of qualification is associated with a lower probability of becoming a mother ( 3 versus 8 per 10'000). If obtaining the baccalauréat opens up life perspectives and the pursuit of studies in higher education, this result would reinforce the hypothesis of opportunity cost evoked above. On the contrary to a higher level of qualification, a lower level of diploma is not associated with a higher probability, at least after the introduction into the regression model of the variable «activity» (passage from model 2 to model 3).

According to the predicted probabilities of our final model (model 3), all other things being equal, teenage women having left home have a probability of having had a child in the year $\mathrm{t}-1$ over ten times higher than those who still live with their parents $\left(87\right.$ per $10^{\prime} 000$ compared to 8 per $\left.10^{\prime} 000\right)$. We can suppose that those having left the parental home and thus begun the transition to adulthood, increase their probability of experiencing another event in this transition - in this case of becoming a parent. However, it is possible that a temporal bias is at the root of this result if in fact the birth of a child is at the origin of the departure from the family home (in order to live with the father of the child, or alone with the child or expulsion by their parents) ${ }^{16}$.

The probability of having had a child is higher in each of our models for young women having declared that they live in a couple (either married or in a consensual union). In the final model this probability is twice as high for those married (17 per 10'000) and three times higher (25 per $10^{\prime} 000$ ) for those in a consensual union compared to those not in a couple. This result confirms the fact that cohabitation remains to an extent a prerequisite of the birth of a child as with older first time mothers (Regnier-Loilier, Solaz, 2010). It is less likely that the effect of marriage is subject to temporal bias, births outside of marriage are no longer stig-

16. It is possible that the difference in probability observed between these two categories is artificially increased due to the fact that teenage mothers living with their parents are more difficult to identify in census microdata via the Own Children method than those enumerated as a head of a household or spouse of head of household (Tomkinson, Breton, 2016). 
matized 17 (Goulet et al., 2001) and «shotgun» marriages instigated by a pregnancy at a young age are rare. That the associated risk with an early entry into motherhood is higher for those in a consensual union compared to those married is a priori unexpected. The effect of consensual unions could be more prone to a temporal bias - the birth of a child serving to consolidate the couple and further formalize the union.

The variable «lives in social housing» was chosen as a proxy variable of belonging to a more deprived area in which socioeconomic and family characteristics associated with a higher risk of teenage pregnancy are more prevalent (Jacquot, 2007; Chevalier, Lebeaupin, 2010). Our logistic regression model indicates only a relatively weak effect upon the probability of having given birth in the year t-1 (11 per 10'000 compared to 8 per $10^{\prime} 000$ for those not living in social housing).

The descriptive statistics show the important effects of age and of origin (defined by immigration status). All other things being equal, only the youngest of teenage women (aged 15 years old) have a lower probability of becoming a mother ( 3 per 10'000). This observation reflects both a lesser probability of becoming pregnant (they are proportionally fewer to be sexually active) and the fact that for the youngest of teenagers, pregnancies are more likely to result in an abortion than a live birth compared to older teenagers (Vilain, Mouquet, 2012). No age effect for women aged between 16 and 18 years is observed once the variables «level of qualification» and especially «activity» are introduced. Similarly, this is the case for the variable «immigration status».

17. The proportion of births outside of marriage has rapidly increased since the beginning of the 1980s and today counts for more than half of all births in metropolitan France (Mazuy et al., 2013). 
TABLE 2 Probability (per 10'000) of having had a child during adolescence in the year $t-1$ (complementary log-log model)

\begin{tabular}{|c|c|c|c|c|c|c|c|}
\hline \multirow{2}{*}{$\begin{array}{l}\text { Variable (i) } \\
\text { Region }\end{array}$} & \multirow{2}{*}{$\begin{array}{l}\text { Modality }(k) \\
\text { Ile-de-France }\end{array}$} & \multicolumn{2}{|c|}{ Model 1} & \multicolumn{2}{|c|}{ Model 2} & \multicolumn{2}{|c|}{ Model 3} \\
\hline & & 20 & - & 8 & - & 6 & - \\
\hline & Auvergne Rhône-Alpes & 20 & - & 7 & - & 5 & - \\
\hline & Nord-Pas-de-Calais Picardie & 51 & - & 15 & - & 9 & - \\
\hline & Aquitaine Limousin Poitou-Charentes & 34 & - & 10 & - & 7 & - \\
\hline & Languedoc-Roussillon Midi-Pyrénées & 33 & - & 10 & - & 7 & - \\
\hline & Alsace Champagne-Ardenne Lorraine & 35 & - & 11 & - & 7 & - \\
\hline & Provence-Alpes-Côtes-d’Azur & 25 & - & 9 & - & 6 & - \\
\hline & Pays de la Loire & 31 & ref. & 10 & ref. & 8 & ref. \\
\hline & Normandie & 36 & - & 10 & - & 7 & - \\
\hline & Bretagne & 26 & - & 9 & - & 7 & - \\
\hline & Bourgogne Franche-Comté & 34 & - & 9 & - & 6 & - \\
\hline & Centre-Val de Loire & 27 & - & 8 & - & 6 & - \\
\hline & Corse & 24 & - & 8 & - & 5 & - \\
\hline \multirow[t]{4}{*}{ Age } & 15 & 6 & $* * *$ & 3 & $* * *$ & 3 & $* * *$ \\
\hline & 16 & 14 & $* * *$ & 6 & $* * *$ & 6 & - \\
\hline & 17 & 31 & ref. & 10 & ref. & 8 & ref. \\
\hline & 18 & 81 & $* * *$ & 14 & $* *$ & 9 & - \\
\hline Immigration & Immigrant & & & 11 & - & 7 & - \\
\hline status & Non immigrant & & & 10 & ref. & 8 & ref. \\
\hline Couple status & In a couple (married) & & & 48 & $* * *$ & 17 & $* * *$ \\
\hline \multirow[t]{2}{*}{ (marital status) } & In a couple (single) & & & 53 & $* * *$ & 25 & $* * *$ \\
\hline & Not in a couple & & & 10 & ref. & 8 & ref. \\
\hline Lives with & Yes & & & 10 & ref. & 8 & ref. \\
\hline parents & No & & & 142 & $* * *$ & 87 & $* * *$ \\
\hline Lives in social & Yes & & & 10 & ref. & 8 & ref. \\
\hline housing & No & & & 17 & $* * *$ & 11 & $* * *$ \\
\hline Level of & Lower than middle school diploma & & & 23 & $* * *$ & 10 & - \\
\hline \multirow[t]{3}{*}{ qualification } & Middle school diploma & & & 10 & ref. & 8 & ref. \\
\hline & Vocational high school diploma & & & 9 & - & 7 & - \\
\hline & High school diploma or higher & & & 2 & $* * *$ & 3 & $* * *$ \\
\hline \multirow[t]{4}{*}{ Activity } & Active, in employment & & & & & 10 & - \\
\hline & Unemployed & & & & & 41 & $* * *$ \\
\hline & Student & & & & & 8 & ref. \\
\hline & Inactive & & & & & 132 & $* * *$ \\
\hline \multicolumn{2}{|l|}{ Constant } & 31 & $* * *$ & 10 & $* * *$ & 8 & $* * *$ \\
\hline \multicolumn{2}{|l|}{ AIC } & $17^{\prime} 946$ & & $13^{\prime} 390$ & & $12^{\prime} 059$ & \\
\hline \multicolumn{2}{|c|}{ Nagelkerke's R² (in \%) } & 6 & & 30 & & 38 & \\
\hline \multicolumn{2}{|c|}{ Concordant pairs (in \%) } & 73 & & 90 & & 91 & \\
\hline \multicolumn{2}{|c|}{$\mathrm{N}$} & \multicolumn{2}{|c|}{ 1'442'543 } & & & & \\
\hline
\end{tabular}

Reference situation: Woman aged 17, residing in Pays de la Loire, not in a couple, living with her parents, not living in social housing, a student with a middle school diploma and not an immigrant.

Note: Levels of significance: ${ }^{* *}: \mathrm{p}<0.00001{ }^{* *}: 0.00001 \leq \mathrm{p}<0.00005 ; *$ : $0.00005 \leq \mathrm{p}<0.0001 ;-: \mathrm{p} \geq$ 0.0001 .

Other intermediate models were tested but are not presented here.

Scope: Women aged 15 to 18 years old in ordinary households, metropolitan France, year $t-1$.

Source: Insee RP 2011 (weighted data). 


\section{Four 'groups' of teenage mothers in metropolitan France}

The statistically significant variables of the final regression model 18 were used to construct a typology of teenage mothers living in metropolitan France. We establish four groups of teenage mothers which we term «inactive with low education», «students», «active with qualifications» and «married».

The first group of teenage mothers «inactive with low education» is the largest (representing $50.2 \%$ of teenage mothers). Table 3 shows that none of the mothers in this group have a diploma higher than middle school level and that almost three quarters have not obtained their middle school diploma. Moreover, all of the women in this group have finished their education. None of these teenage mothers work and amongst those inactive ( $70 \%$ of the group), three quarters declare themselves as being a housewife. This could signify a renunciation of an eventual entry into the labour market in order to focus upon family life. The rate of activity ${ }^{19}$ increases however with the age at birth, increasing from $12 \%$ amongst those having had their child aged 16 to 37\% amongst the oldest teenage mothers. Regarding the teenage mothers having given birth aged 18, they have almost all (98\% of them) left home and almost half $(48 \%)$ are in a situation of single parenthood. This group of teenage mothers is overrepresented in the region of Nord-Pas-de-Calais Picardie (Figure 3) where almost two thirds of teenage mothers belong to this group (compared to 50\% in metropolitan France). Conversely, only a third of teenage mothers in the Ile-de-France region are «inactive with low education».

The second group in terms of prevalence is that of the «students» (24.6\%). This group is the youngest out of the four groups, the mothers having had their child on average during the year of their $16^{\text {th }}$ birthday. More than 9 out of 10 mothers in this group are students and in general have obtained some grade of diploma, more than 1 in 5 having already obtained their high school diploma. More than half (57\%) of those having the baccalauréat are pursuing their studies. It is in this group that the proportion of teenage mothers living with their mothers is the highest, continued cohabitation with parents probably being a condition which enables a continued enrollment in education. Those mothers who are no longer living in the parental home are older on average, almost two thirds having had their child aged 18. This group is characterized by

\footnotetext{
18. All except age.

19. Strictly in terms of «economic activity», as those active are unemployed.
} 
a relatively smaller proportion that live in social housing, especially amongst those living with their parents. Outside of the oldest mothers and those having left home, the mothers in this group rarely declare to be living in a couple. The «students» are particularly prevalent in Ile-deFrance (39\% versus 24\% in metropolitan France).

TABLE 3 Typology of teenage mothers in 4 groups

\begin{tabular}{|c|c|c|c|c|}
\hline & $\begin{array}{l}\text { «Inactive with } \\
\text { low education» }\end{array}$ & «Students» & $\begin{array}{l}\text { "Active with } \\
\text { qualifications» }\end{array}$ & «Married» \\
\hline $\mathrm{N}$ & $2^{\prime} 230$ & $1^{\prime} 094$ & 849 & 272 \\
\hline$\%$ & 50.2 & 24.6 & 19.1 & 6.1 \\
\hline Mean age & 17.5 & 16.9 & 17.6 & 17.8 \\
\hline \multicolumn{5}{|l|}{ Couple status } \\
\hline In a couple (married) & 0.0 & 0.0 & 0.0 & 100.0 \\
\hline In a couple (single) & 52.0 & 18.5 & 53.6 & 0.0 \\
\hline Not in a couple & 48.0 & 81.5 & 46.4 & 0.0 \\
\hline \multicolumn{5}{|l|}{ Lives with parents } \\
\hline Yes & 17.6 & 53.3 & 23.3 & 8.3 \\
\hline No & 82.4 & 46.7 & 76.7 & 91.7 \\
\hline \multicolumn{5}{|l|}{ Level of qualification } \\
\hline Lower than middle school diploma & 73.4 & 22.8 & 9.1 & 55.1 \\
\hline Middle school diploma & 26.6 & 48.2 & 7.9 & 18.4 \\
\hline Vocational high school diploma & 0.0 & 7.7 & 75.7 & 13.2 \\
\hline High school diploma or higher & 0.0 & 21.3 & 7.3 & 13.3 \\
\hline \multicolumn{5}{|l|}{ Activity } \\
\hline Active, in employment & 0.0 & 0.0 & 33.5 & 7.3 \\
\hline Unemployed & 30.9 & 3.1 & 27.8 & 24.4 \\
\hline Student & 0.0 & 90.9 & 6.6 & 4.9 \\
\hline Inactive & 69.1 & 6.0 & 32.0 & 63.5 \\
\hline \multicolumn{5}{|l|}{ Lives in social housing } \\
\hline Yes & 31.5 & 28.7 & 38.0 & 35.6 \\
\hline No & 68.5 & 71.3 & 62.0 & 64.4 \\
\hline \multicolumn{5}{|l|}{ Immigration status } \\
\hline Immigrant & 7.0 & 9.3 & 6.4 & 44.9 \\
\hline Non immigrant & 93.0 & 90.7 & 93.6 & 55.1 \\
\hline
\end{tabular}

Note: The variables active in the construction of the typology were couple status, lives with parents, level of qualification, activity and lives in social housing.

Scope: Women aged 15 to 18 years old in ordinary households having had a child in $t-1$, metropolitan France, year $t-1$.

Source: Insee RP 2011 (weighted data).

The third group of teenage mothers is that of those «active with qualifications» $(19.1 \%)$. More than $60 \%$ of mothers in this group are economically active, of which more than half (55\%) are in employment. The vast majority have a diploma, in most cases a vocational high school diploma. Half of the teenage mothers in this group declare that they live in a con- 
sensual union, the proportion being higher amongst those having left home (60\% compared to $33 \%$ amongst those still living at home). The teenage mothers «active with qualifications» that have moved out of the family home are fewer to be living in social housing (35\% against $47 \%$ of those cohabiting with their parents). Somewhat paradoxically, it is those who are unemployed who are proportionally more to have left home ( $89 \%$ versus $71 \%$ of those in employment). The mothers of this group are more present in the region of Bourgogne Franche-Comte and are underrepresented in the north-east of France.

FIGURE 3 Overrepresentation of the four groups of teenage mothers in the regions of France

«Inactive with low education»
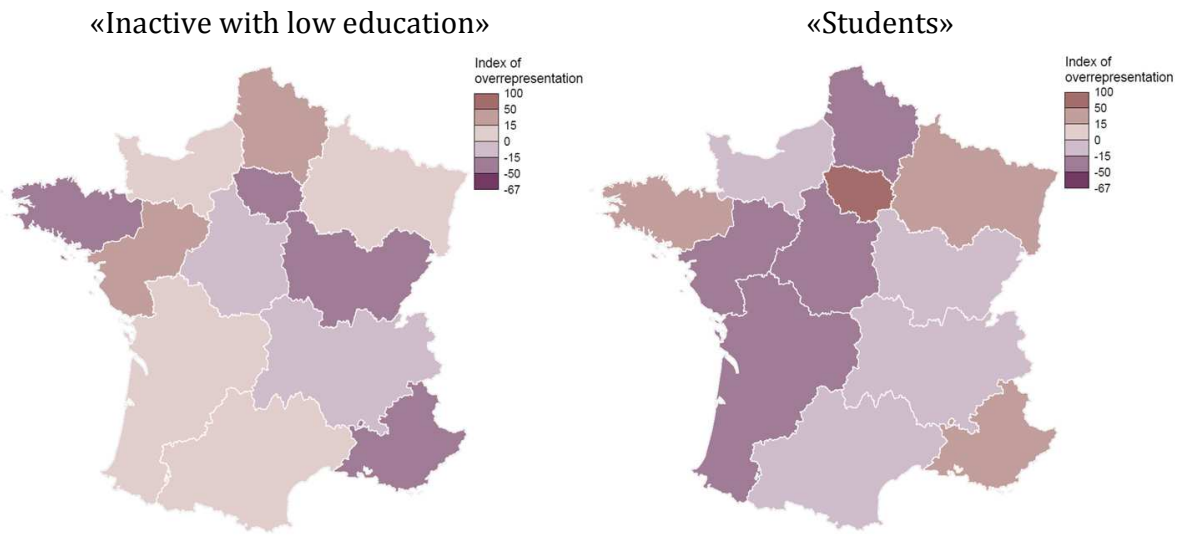

«Active with qualifications»

«Married»
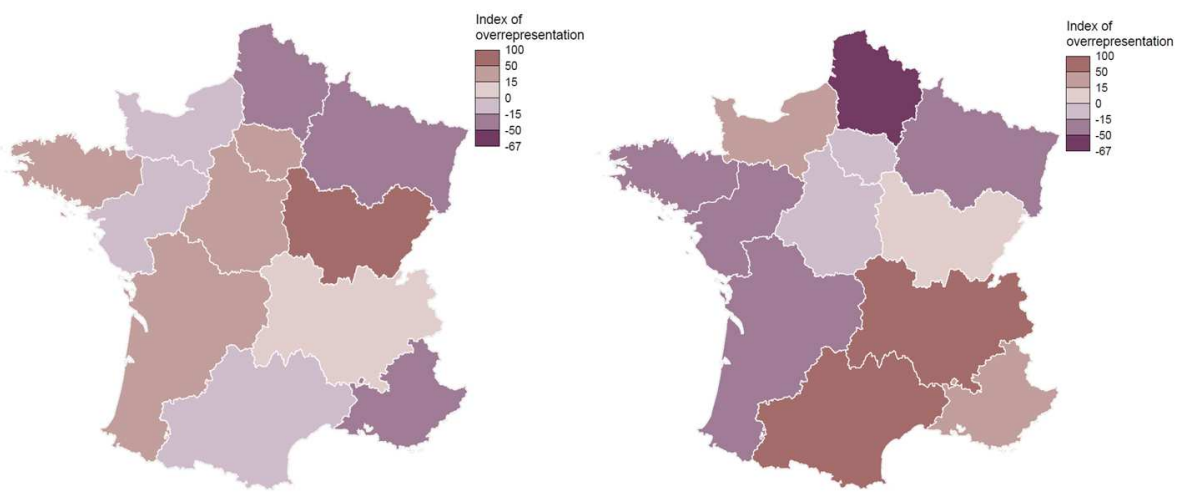

Note: The results for the region Corse are not shown as only 15 teenage mothers were observed in this region.

Scope: Women aged 15 to 18 years old in ordinary households having had a child in $t-1$, metropolitan France, year $t-1$.

Sources: Insee RP 2011, IGN GEOFLA ${ }^{\circledast}$. 
The final group consisting of «married» teenage mothers is the smallest counting for less than one in ten teenage mothers (6.1\%). Each of the mothers in this group are married with the vast majority (92\%) having left home. They are the oldest group of teenage mothers having had, on average, their child aged almost 18 years old (17.8). For the most part, the «married» teenage mothers have a low level of education - more than half not having obtained their middle school diploma - and are mostly inactive. These two characteristics seem to indicate within their families a traditional model of the male breadwinner. Although teenage mothers having immigrated to France are proportionally more in this group ( $45 \%$ versus $10 \%$ on the whole), they remain in the minority. The husbands of these «married» teenage mothers are in each case older than their wife, the median age gap between spouses being 5 years although varying largely - in a quarter of cases the husband is more than 10 years older than his wife. The husbands are in the majority active in employment (55\%) or unemployed (33\%). This group is overrepresented in south-east France with the proportion in the Auvergne RhôneAlpes region being twice as high as in metropolitan France $112 \%$ compared to $6 \%$ ).

\section{Conclusion}

Using sociodemographic data from census microdata and an application of a refined version of the Own Children method, we have been able to identify the teenage women having given birth to a child in the year preceding the census and create sociodemographic profiles of this distinct sub-population.

Our results show that observed regional differences depend in part upon the composition of the sociodemographic characteristics of the teenage women who reside there. These different structures are at the origin of the overrepresentation of certain groups of teenage mothers within regions.

Our results are in keeping with theories of the transition to adulthood, the women having the greatest probability of becoming a teenage mother are those having left school and without an economic activity as well as those who are in a cohabiting couple. An entry into motherhood, arriving classically at the end of the sequence of events which define the transition to adulthood, accelerates the transition to adulthood for these young women. 
If those teenage women having had a child distinguish themselves from those who have not, there remains amongst teenage mothers an important heterogeneity as shown by the four profiles of teenage mothers described above. Our dual approach highlights the importance of distinguishing the profiles «at risk» and the profiles observed. If for example inactivity is strongly associated with teenage childbearing, it is important to emphasize that a third of teenage mothers are either studying or in employment.

As rich as they are, the census microdata exploited in this work cannot explain some elements central to the analysis of teenage fertility such as sexual and contraceptive behaviour. Also, the heterogeneous profiles of teenage mothers at the moment of their entry into motherhood demonstrated in this article will probably lead to different social and familial life courses in the future. Further research is necessary in order to treat these elements.

\section{References}

Abbası-Shavazı M. (1997), «An Assessment of the Own-Children Method of Estimating Fertility by Birthplace in Australia», Journal of the Australian Population Association, 14 (2), pp. 167-185.

ARAI L. (2007), «Peer and Neighbourhood Influences on Teenage Pregnancy and Fertility: Qualitative Findings from Research in English Communities», Health \& Place, 13 (1), pp. 87-98, https://doi.org/10.1016/j.healthplace.2005.10.003.

Battagliola F., Brown E., JaSPard M. (1997a), "Être parent jeune : quels liens avec les itinéraires professionnels ?», Économie et Statistique, 304-305, pp. 191-207, https://doi.org/10.3406/estat.1997.2565.

Battagliola F., Brown E., JASPARd M. (1997b), "Itinéraires de passage à l'âge adulte: différences de sexe, différences de classe», Sociétés Contemporaines, 25, pp. 85-103, https://doi.org/10.3406/socco.1997.1436.

Berthoud R. (2001), "Teenage Births to Ethnic Minority Women», Population Trends, 104, pp. 12-17.

Breton D., Prioux F. (2009), "The One-Child Family: France in the European Context», Demographic Research, 20, pp. 657-692, https://doi.org/10.4054/DemRes. 2009.20.27.

Chevalier C., Lebeaupin F. (2010), "La population des zones urbaines sensibles», Insee Première, 1 328, $4 \mathrm{p}$. 
Coleman D., Dubuc S. (2010), "The Fertility of Ethnic Minorities in the UK, 1960s2006», Population Studies, 64 (1), pp. 19-41, https://doi.org/10.1080/ 00324720903391201.

Cook S., Cameron S. (2015), "Social Issues of Teenage Pregnancy», Obstetrics, Gynaecology \& Reproductive Medicine, 25 (9), pp. 243-248, https://doi.org/10.1016/j. ogrm.2015.06.001.

Cater S., Coleman L. (2006), "Planned» Teenage Pregnancy, Bristol, The Policy Press, $80 \mathrm{p}$.

Charbonneau J. (2000), "Alternative Life Paths Among Adolescent Mothers: A Case Study in the Montréal Area», INRS-Urbanisation Working Paper, 2000-03, 16 p.

DAguerRe A. (2010), "Les grossesses adolescentes en France et en Grande-Bretagne», Informations Sociales, 2010/1, 157, pp. 96-102.

Davie E., MAzuy M. (2010), "Fécondité et niveau d'études des femmes en France à partir des enquêtes annuelles de recensement», Population, 65 (3), pp. 475-511, https://doi.org/10.3917/popu.1003.0475.

DesPlanques G. (1993), «Mesurer les disparités de fécondité à l'aide du seul recensement», Population, 48 (6), pp. 2 011-2 023.

Desplanques G. (2008), «Avantages et incertitudes des enquêtes annuelles de recensement en France», Population, 63 (3), pp. 477-501, https://doi.org/10.3917/ popu.803.0477.

DeSPLANQUES G. (2011), «Les disparités géographiques de fécondité en France», Espace, Populations, Sociétés, (3), pp. 459-473, https://doi.org/10.4000/eps.4649.

Ekert-Jaffe O., Joshi H., Lynch K., Mougin R., Rendall M. (2002), «Fécondité, calendrier des naissances et milieu social en France et en Grande-Bretagne : politiques sociales et polarisation socio-professionnelle», Population, 57 (3), pp. 485-518, https://doi.org/10.3917/popu.203.0485.

GallaND O. (1995), "Une entrée de plus en plus tardive dans la vie adulte», Économie et Statistique, 283-284, pp. 33-52, https://doi.org/10.3406/estat.1995.5961.

GALLAND O. (2000), «Entrer dans la vie adulte: des étapes toujours plus tardives, mais resserrées», Économie et Statistique, 337-338, pp. 13-36, https://doi.org/10. 3406/estat.2000.7494.

Genest L., Decroix H., Rotten D., Simmat-DuRAnd L. (2014), «Maternités précoces : profils sociodémographiques de 220 mères adolescentes en Seine-Saint-Denis», Journal de Gynécologie Obstétrique et Biologie de La Reproduction, 43 (5), pp. 351360, https://doi.org/10.1016/j.jgyn.2013.03.009.

Girma S., PAton D. (2015), "Is Education the Best Contraception: The Case of Teenage Pregnancy in England?», Social Science \& Medicine, 131, pp. 1-9, https://doi. org/10.1016/j.socscimed.2015.02.040

Goulet C., Marcil I., Kamdom C., Toussaint-Lachance M. (2001), «Le point sur les mères adolescentes au Québec», Ruptures, 8 (2), pp. 21-34. 
GrabiLl W., Cho L.-J. (1965), «Methodology for the Measurement of Current Fertility From Population Data on Young Children», Demography, 2, pp. 50-73, https:// doi.org/10.2307/2060106.

JACQuot A. (2007), «L'occupation du parc HLM : un éclairage à partir des enquêtes logement de l'Insee», Insee Documents de Travail, F0708, 67 p.

Kearney M., Levine P. (2012), «Why is the Teen Birth Rate in the United States So High and Why Does It Matter?», Journal of Economic Perspectives, 26 (2), pp. 141166, https://doi.org/10.1257/jep.26.2.141.

LEFRANC C. (2010), «La diffusion des résultats du recensement rénové de la population", Courrier des Statistiques, 129, $6 \mathrm{p}$.

LeIBowitz, A. EISEN M., CHow W. (1986), «An Economic Model of Teenage Pregnancy Decision-Making», Demography, 23 (1), pp.67-77, https://doi.org/10.2307/ 2061408.

Lesthaeghe R., VAN De KAA D. (1986) "Twee Demografische Transities?», R. LeSTHAEGHE, D. VAN DE KAA (eds), Bevolking: Groei en Krimp, Deventer, Van Loghum Slaterus, pp. 9-24.

LUPTON R., KNEALE D. (2010), «Are There Neighbourhood Effects on Teenage Parenthood in the UK, and Does it Matter for Policy? A Review of Theory and Evidence», CASE Papers 141, London, Centre for the Analysis of Social Exclusion, London School of Economics and Political Science, $29 \mathrm{p}$.

MANLove J. (1997), «Early Motherhood in an Intergenerational Perspective: The Experiences of a British Cohort», Journal of Marriage and Family, 59 (2), pp. 263-279, https://doi.org/10.2307/353469.

MAZUY M., BARBIERI M., D'ALBIS H. (2013), "L'évolution démographique récente en France : la fécondité est stable», Population, 68 (3), pp. 385-432, https://doi.org/ 10.3917/popu.1303.0385.

McCulloch A. (2001), "Teenage Childbearing in Great Britain and the Spatial Concentration of Poverty Households», Journal of Epidemiology \& Community Health, 55 (1), pp. 16-23, https://doi.org/10.1136/jech.55.1.16.

Ní Bhrolcháin M., Beaujouan E. (2012), «Fertility Postponement is Largely due to Rising Educational Enrolment», Population Studies, 66 (3), pp. 311-327, https://doi. org/10.1080/00324728.2012.697569.

PIson G. (2010), «France 2009 : l'âge moyen à la maternité atteint 30 ans», Population et Sociétés, 465, $4 \mathrm{p}$.

Prioux F., Mazuy M. (2009), "L'évolution démographique récente en France: dix ans pour le Pacs, plus d'un million de contractants», Population, 64 (3), pp. 445494, https://doi.org/10.3917/popu.903.0445.

RegNier-Lollier A., SOlaz A. (2010), "La décision d'avoir un enfant : une liberté sous contraintes», Politiques Sociales et Familiales, 100, pp.61-77, https://doi.org/10. 3406/caf.2010.2526. 
ReNDALL M. (2003), «How Important are Intergenerational Cycles of Teenage Motherhood in England and Wales? A Comparison with France», Population Trends, 111, pp. 27-37.

Robson K., Pevalin D. (2007), «Gender Differences in the Predictors and Socio-Economic Outcomes of Young Parenthood in Great Britain", Research in Social Stratification and Mobility, 25 (3), pp. 205-218, https://doi.org/10.1016/j.rssm.2007.08. 002.

RowLANDS S. (2010), "Social Predictors of Repeat Adolescent Pregnancy and Focused Strategies», Best Practice \& Research Clinical Obstetrics \& Gynaecology, 24 (5), pp. 605-616, https://doi.org/10.1016/j.bpobgyn.2010.02.016.

Russell S. (2002), "Childhood Developmental Risk for Teen Childbearing in Britain», Journal of Research on Adolescence, 12 (3), pp. 305-324, https://doi.org/10.1111/ 1532-7795.00035.

SMITH T. (1993), «Influence of Socioeconomic Factors on Attaining Targets for Reducing Teenage Pregnancies», British Medical Journal, 306, pp. 1'232-1'235.

STANFORS M., SCOTT K. (2013), «Intergenerational Transmission of Young Motherhood. Evidence from Sweden, 1986-2009», The History of the Family, 18 (2), pp. 187-208, https://doi.org/10.1080/1081602X.2013.817348.

TOMKINSON J., Breton D. (2016), «Note sur l'identification des mères adolescentes dans le recensement français via la méthode du décompte d'enfants au foyer», IDUS Working Paper, $15 \mathrm{p}$.

Van Bavel J., Nitsche N. (2013), “'The Proper Age for Parenthood' and Second Birth Rates in Europe», European Sociological Review, 29 (6), pp. 1'149-1'161.

Vilain A., Mouquet M.-C. (2012), "Les interruptions volontaires de grossesse en 2010», Études et Résultats, 804, 6 p.

Wellings K., Nanchahal K., Macdowall W., Mcmanus S., Erens B., Mercer C., Johnson M., Copas A., Korovessis C., Fenton K., Field J. (2001), «Sexual Behaviour in Britain: Early Heterosexual Experience», The Lancet, 358, pp. 1'843-1'850. 


\section{Appendices}

\section{Appendix 1 Map of the 13 French regions}

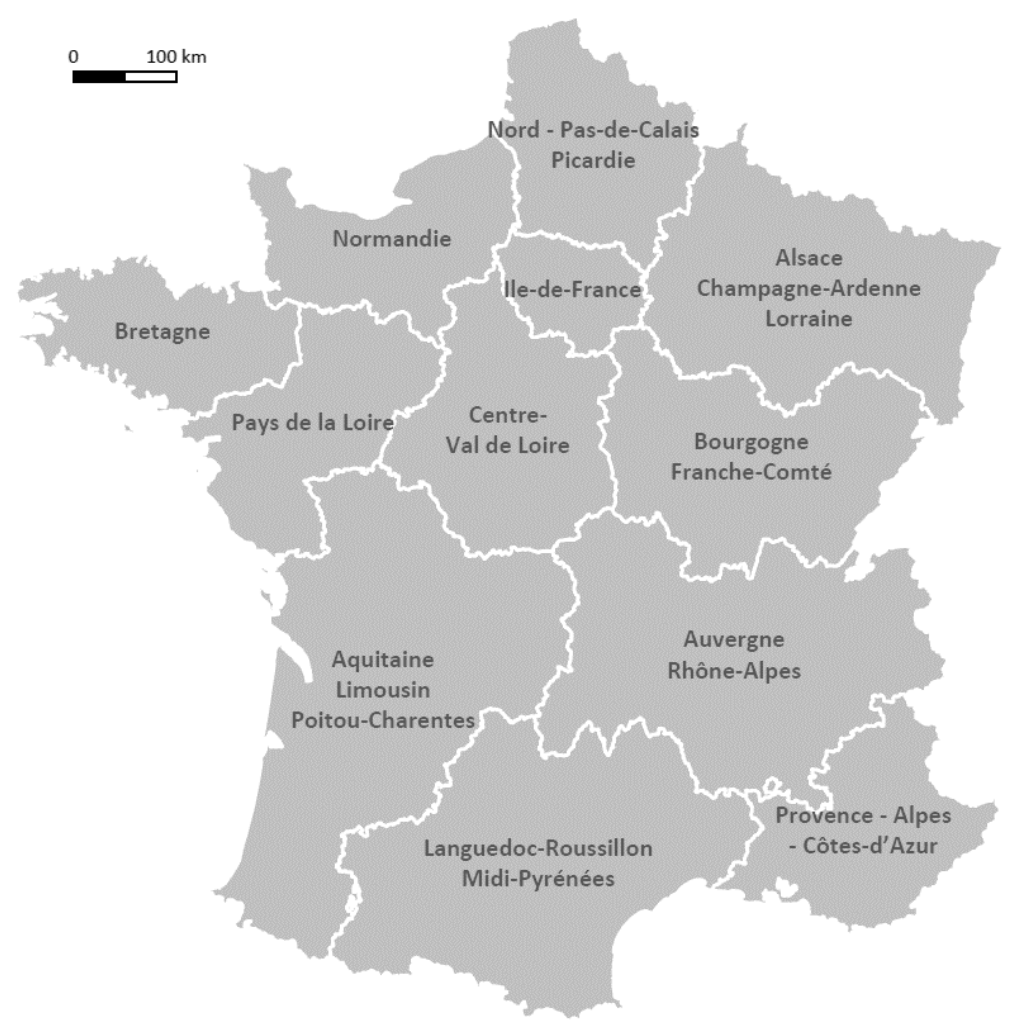

Source: IGN GEOFLA ${ }^{\circledast}$. 
Appendix 2 Extract from the French birth registration form:

"Information concerning the mother» section

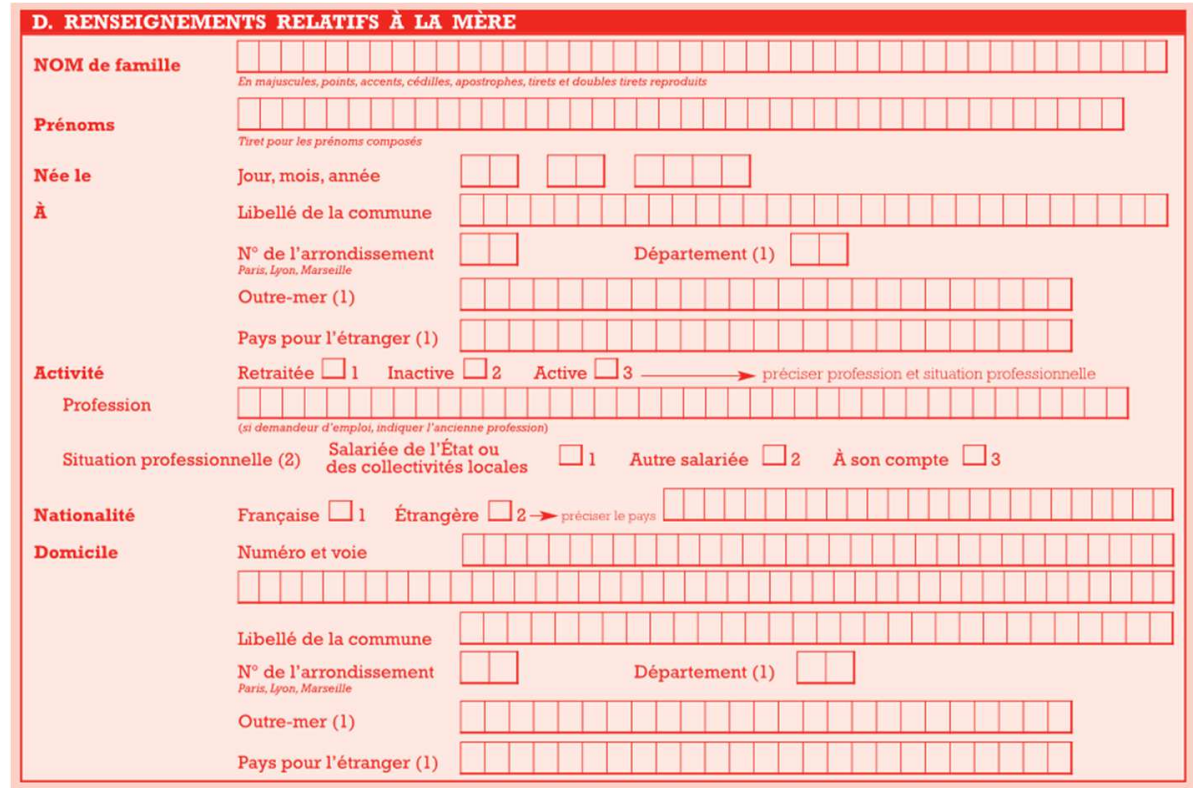

Source: Insee, www.insee.fr/fr/methodes/sources/pdf/Bulletin_de_naissance_5.pdf. 


\section{Appendix 3 Descriptive statistics, distribution (in \%) of women aged 15-18 years old, having had a child in the year $t-1$ or not, by region of residence and certain sociodemographic characteristics}

\begin{tabular}{|c|c|c|}
\hline & \multicolumn{2}{|c|}{ Had a child during the year $t-1$} \\
\hline & Yes & No \\
\hline & 0.3 & 99.7 \\
\hline \multicolumn{3}{|l|}{ Age } \\
\hline 15 & 4.9 & 25.2 \\
\hline 16 & 10.6 & 25.4 \\
\hline 17 & 24.5 & 25.4 \\
\hline 18 & 60.1 & 24.1 \\
\hline \multicolumn{3}{|l|}{ Couple status } \\
\hline In a couple (married) & 3.5 & 0.2 \\
\hline In a couple (single) & 33.4 & 1.7 \\
\hline Not in a couple & 63.1 & 98.2 \\
\hline \multicolumn{3}{|l|}{ Lives with parents } \\
\hline Yes & 52.6 & 91.5 \\
\hline No & 47.4 & 8.5 \\
\hline \multicolumn{3}{|l|}{ Level of qualification } \\
\hline Lower than middle school diploma & 46.4 & 19.0 \\
\hline Middle school diploma & 34.9 & 58.0 \\
\hline Vocational high school diploma & 10.8 & 9.3 \\
\hline High school diploma or higher & 7.9 & 13.7 \\
\hline \multicolumn{3}{|l|}{ Activity } \\
\hline Active, in employment & 8.3 & 6.5 \\
\hline Unemployed & 13.5 & 3.9 \\
\hline Student & 42.0 & 87.1 \\
\hline Inactive & 36.2 & 2.5 \\
\hline \multicolumn{3}{|l|}{ Lives in social housing } \\
\hline Yes & 31.2 & 19.8 \\
\hline No & 68.8 & 80.2 \\
\hline \multicolumn{3}{|l|}{ Immigration status } \\
\hline Immigrant & 8.3 & 4.0 \\
\hline Non immigrant & 91.7 & 96.0 \\
\hline
\end{tabular}

Scope: Women aged 15 to 18 years old in ordinary households, metropolitan France, year $t$ 1.

Source: Insee RP 2011 (weighted data).

Note: Percentages are standardised by age using a reference population (that of all women aged between 15 and 18 years old (age attained in the calendar year) in the year $t-1)$. 